Menara Perkebunan, 2000, 68 (1),10-19

\title{
Nucleotide sequence of cryIA gene cloned from Btk isolate of Bacillus thuringiensis and comparison with cryIA(c) gene from B. thuringiensis subsp. kenyae
}

\author{
Sekuen nukleotida gen cryIA dari B.thuringiensis isolat Btk dibandingkan \\ dengan gen crylA(c) dari B. thuringiensis subsp. Kenyae \\ Asmini BUDIANI \& Djoko SANTOSO \\ Biotechnology Research Unit for Estate Crops, Bogor 16151, Indonesia
}

\begin{abstract}
Ringkasan
Perakitan tanaman perkebunan yang toleran terhadap serangga hama dapat ditempuh melalui rekayasa genetika menggunakan gen cry. Gen cryIA merupakan gen cry yang paling banyak dipelajari di antara gen cry lainnya. Berdasarkan homology sekuen dan spesifisitas protein yang disandinya terhadap serangga sasaran, gen ini telah diklasifikasikan menjadi 10 subklas. Tulisan ini melaporkan hasil sekuensing (ragmen gen cryIA penyandi domain toksin yang diisolasi dengan teknik PCR dari Bacillus thuringiensis isolat Btk dan diklon menggunakan vektor pGEMT. Untuk menentukan sekuen gen cryIA yang berukuran sekitar 2 kb tersebut, dilakukan konstruksi satu seri mutan terdelesi searah dari ujung 5' menggunakan kit Erase-a-Base-System. Tiga DNA gen cryIA mutan dengan tingkat delesi yang sesuai dan satu nonmutan dipilih untuk sekuensing DNAnya. Sekuensing dilakukan dari satu arah menggunakan primer universal SP6 pada alat ABI 377A automatic DNA sequencer. Sekuen lengkap dari gen cryIA diperoleh dengan cara menggabungkan sekuen ketiga mutan dengan sekuen dari gen cryIA nonmutan secara manual. Untuk konfirmasi sekuen ujung 3', dilakukan sekuensing dari arah lainnya menggunakan primer universal T7. Sekuen lengkap dari fragmen tersebut mengandung 2021 nukleotida dan menyandi protein dengan 673 asam amino. Dibandingkan dengan sekuen gen crylA(c) dari B. thuringiensis subsp. kenyae, terlihat adanya sepuluh mutasi titik masing-masing pada nukleotida ke 444, 477, 1089, 1092, 1098, 1242, 1566, 1869, 1906 dan 1961. Tujuh mutasi titik pada nukleotida ke 444, 477, 1089, 1092, 1242, 1566, dan 1869 tidak merubah asam amino, sedangkan tiga mutasi lainnya mengakibatkan perubahan asam amino, yaitu pada nukleotida ke 1098 (kodon ke 366, yang menyebabkan perubahan dari Phe menjadi Leu), nukleotida ke 1906 (kodon ke 636, yang mengubah Val menjadi Leu) dan pada nukleotida ke 1961(kodon ke 654, yang mengubah Cys menjadi Tyr).
\end{abstract}

\section{Summary}

Estate crops tolerant to pests can be development through genetic engineering using cry gene. CryIA is the best studied among cry genes. Based on the sequence homology and specificity of their encoded proteins to the, targeted insect, these genes have been classified into 10 subclasses. This paper reports sequencing of cryIA gene fragment en-coding toxin 
domain isolated from Btk isolates of Bacillus thuringiensis using PCR technique and cloned with pGEM-T vector. To determine the full sequence of the 2-kb gene fragment, a series of mutants uni-directionally deleted at the 5'-end were constructed. Mutation was done using Erase-a Base-System kit. Three DNA mutants with appropriate degree of deletion and the unmutated DNA were chosen for sequencing. Sequencing was conducted from one direction with SP6 universal primer using the ABI 377A automatic DNA sequencer. The full sequence of cryIA fragment was assembled manually using the sequences of DNA mutants and the nonmutant cryIA fragment. To confirm the sequence of the 3'-end, sequencing from the other direction was performed using the $\mathrm{T} 7$ universal primer.The completed sequence of the fragment contains 2021 nucleotides encoding a protein of 673 amino acids. Compares to the sequence of cryIA(c) from B. thuringiensis subsp. kenyae, it was shown that there were ten point mutations (nucleotides of 444, 477, 1089, 1092, 1098, 1242, 1566, 1869, 1906 and 1961), sevent of them (nucleotides of 444, 477, 1089, 1092, 1242, 1566 and 1869) were identified as silent mutations, while the other three substituted the amino acids, which are at the nucleotide 1089 (codon 366, substitution of Leu for Phe), nucleotide 1906 (codon 636, substitution of Leu for Val), and nucleotide 1961 (codon 654, substitution of Tyr for Cys).

[Keywords: cryIA(c) gene, Bacillus thuringiensis, DNA sequencing, uni-deleted mutant]

\section{Introduction}

Bacillus thuringiensis (BT) is a grampositive, spore-forming bacterium that produces an insecticidal protein. There are more than 30 recognized subspecies or varieties of BT. The majority of them produce crystals, which are composed of proteins called Sendotoxin and have highly specific insecticidal activity (Udayasurian et al., 1994). Most crystal proteins are protoxins which are proteolitically converted into smaller toxic polypeptides in the insect midgut. The activated toxin interacts with the midgut epithelium cells of susceptible insects, generating pores in the cell membrane that disturbs the osmotic balance leading to midgut cell swelling and lyses (Hofte \& Whiteley, 1989; Ceron et al., 1995).

BT formulations have been in commercial use for the past 30 years and account for $90-95$ $\%$ of the total biopesticide market (Udayasurian et al., 1994). As a biological insecticide, BT has an advantage compared to chemical insecticides, as BT toxin is considered to be environmentally safe. However, the disadvantage of BT bioinsecticides is their low field stability and narrow specificity (Herrera et al., 1994; de Maagd et al., 1999). Other powerful alternative strategies for crop protection against insect damage are cloning of cry genes and expressing them in the plantassociated microorganisms or transgenic plants. In transgenic plants, the toxin is continuously produced and protected against degradation. Its expression could also be directed specifically in the. targeted tissue. The problem of narrow specificity may be overcome by simultaneously expressing genes for proteins with different specificities (de Maagd et al., 1999).

Many of the cry genes have been cloned and sequenced. Nucleotide sequences have been reported for more than 42 crystal protein-encoding genes (Hofte \& Whiteley, 1989). These genes have been organized into six different groups based on their sequence similarities and specificity of the protein. The CryI, CryII, CrylII, CrylV, CryV proteins are toxic respectively to Lepidopterans, Lepidopterans and Dipterans, Coleopterans, Dipterans, Lepidopterans and Coleopterans (Tailor et al., 1992; Ceron et al., 1995; Shin et al., 1995). CryVI which is toxic to nematodes was proposed 
by Aronson (1993). Among them CryI proteins are the best studied crystal proteins. Ceron et al. (1995) classified these proteins into 10 different subclasses (CrylA (a) - CrylF(a)), each of which has a specific range of activity against different Lepidopteran insects.

DNA sequence can be elucidated using chemical or enzymatic methods. The enzymatic method of Sanger et al. (1977) is based on the ability of a DNA polymerase to extend a primer hybridized to the DNA template that is to be sequenced, until a chain-terminating nucleotide is incorporated. A set of sequencing reactions performed manually could read approximately 400 bases, while the automatic DNA sequencer has a reliable accuracy up to about 500 bases. Therefore, to determine the 2-kb cryIA sequence which is cloned in pGEM-T, construction of a pGEM-cryIA mutants series is needed (Sambrook et al., 1989).

We have isolated toxin domain of cryIA gene from Btk isolates of $B$. thuringiensis by PCR method. Primers used were designed from the DNA sequence of cryIA(c) reported by Von Tersch et al. (1991). The PCR products have been cloned with pGEM-T vector into $E$. coli JM109 and DH5a (Budiani et al., 1996; Budiani et al., 1999; Santoso et al., 2000). This paper reports the elucidation of the DNA sequence of the cryIA fragment by construction of a series of uni-directionally deleted mutants. The sequence was then compared with that of cryLA(c) cloned from $B$. thuringiensis subsp. Kenyae HD588-2 from which the primers were designed. From the DNA sequence, we deduce the sequence of amino acid.

\section{Materials and Methods}

\section{Isolation and cloning of cryIA gene fragment}

Toxin domain of cry1(A) gene which is approximately $2 \mathrm{~kb}$ was isolated from Btk isolates of B. thuringiensis by PCR method as reported previously (Budiani et al., 1996). The primers used were designed based on the DNA sequences of the cryIA(c) gene from $B$. thuringiensis subsp. kenyae. The isolated genes were cloned using pGEM-T vector in E. coli DH5a and E. coli JM109 (Budiani et al., 1999).

\section{Isolation of recombinant plasmid}

Before plasmid isolation for sequencing, bacterial clones were screened to examine the presence of stable pGEM-cry recombinant plasmid by quick plasmid preparation from $E$. coli using Speedy method (Schnable, 1991). The prepared plasmids were run on agarose gel and the presence of 5-kb DNA band on the gel indicates that the pGEM-cry is stable. Isolation of recombinant plasmid for sequencing was then done using Quantum Prep Kit (BioRad, CA-USA) with the experimental procedure as recommended by the manufarfiirnr

\section{Construction of uni-deleted mutants}

To determine the sequence of cryIA gene cloned in pGEM-T vector, a series of pGEMcry mutants uni-directionally deleted at the 5'-end was constructed. The mutants were needed because the automatic DNA sequencer equipped with computerized analysis has a reliable accuracy only up to about 500 bases. The pGEM-cry recombinant was uni-directionally deleted at the 5'-end of the cryIA gene using Erase a Base system kit (Promega, WI-USA). The recombinant plasmid was double digested with Apal and Ncol restriction enzymes in order to direct exonuclease III deletion occurring at the 5'- end of the linearized plasmid. The next steps 
were sequentially digestion of about $30 \%$ reaction volume with exonuclease III, S1 digestion, flushing with Klenow and circularization of the DNA using T4 ligase. The procedure was adopted from the manufacturer's manual as reported by Santoso (1998).

\section{Transformation of mutated clones}

Ligation products of uni-deleted mutants were transformed into competent cells of E. coli strain DH5a. Preparation of competent cells was done with the method described by Doyle (1996) and transformation procedure was adopted from Schnable (1991). Transformation was completed by heat shocking a mixture of $100 \mathrm{pL}$ competent cells and $10 \mathrm{pL}$ ligation product in a $42^{\circ} \mathrm{C}$ water bath for 90 seconds. After $2 \mathrm{~min}$. incubation in ice, $200 \mathrm{gL}$ SOC medium was added and the mixture was then cultured at $37^{\circ} \mathrm{C}$ for one hour with 75 -rpm shaking. Afterwards, the bacterial cultures were plated on agar solidified LB medium containing $100 \mathrm{gL} / \mathrm{mL}$ ampicillin.

\section{DNA sequencing}

Each of the mutant DNAs was isolated from E. coli using kit of Quantum Prep. Three appropriate mutants and non-mutated pGEM-cry were selected for DNA sequencing, which was conducted at The Eijkman Institute for Molecular Biology. For good results, DNA was purified by Qiagen purification kit. Sequencing was conducted from one direction with SP6 universal primer using the ABI 377A automatic DNA sequencer. To confirm the sequence of the 3'-end, sequencing from the other direction was performed using the $\mathrm{T} 7$ universal primer.

\section{Results and Discussion}

\section{Construction of uni-deleted mutant}

An efficient way to sequence the 2-kb cryIA gene cloned in pGEM-T vector is to generate a nested set of deletion in this target gene. By this way the priming site is effectively moved closer to the sequence of interest. Furthermore, these mutants of pGEMcry could then be sequenced based on enzymatic method of Sanger et al. (1977) using only one oligomer DNA primer, and the entire sequence of cryIA gene can be obtained by joining the sequence of mutants.

Experimental steps for the construction of a series of pGEM-cry mutants uni-directionally deleted is presented schematically in Figure 1.

The recombinant plasmid of pGEMcryIA was first linearized by double digestion using endonucleases Apal and Ncol. These enzymes cut DNA close to the priming site. Recognizing and cutting at the restriction site of GGGCC'C and $\mathrm{C}^{\prime} \mathrm{CATGG}$ respectively, these enzymes should generate a four bases 3'-protrusion and leave a 5'-overhang adjacent to the cryIA from which deletion takes place. The four bases 3'-protrusion is resistant to exonuclease activity (Rogers \& Weiss, 1980), while the 5'-overhang is susceptible to the exonuclease. After exonuclease deletion, samples were removed at time intervals and added to tubes containing S1 Nuclease, which removes the remaining ssDNA tails. These samples were then fractionated with agarose gel electrophoresis. Figure 2 shows the electrtrophoresic profile of the mutants. It is shown that digestion by ExoIII proceeded perfectly.

The mutated pGEM-cryIA was selfligated to circularize and transformed into bacterial host (E. coli JM109). The transformed cells were spread on selection medium containing 
Figure 1. Schematic diagram of construction of a series of pGEM-cry mutants unidirectionally deleted at the 5 ' end of cry gene using kit of Erase-a-Base System

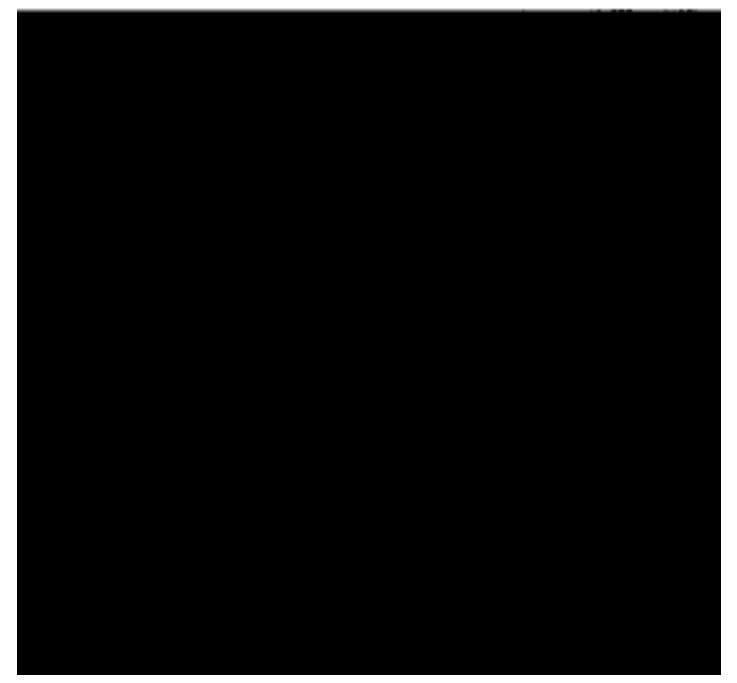

Figure 2. Electrophoretic profile of pGEM-cryIA after Exolll digestion at four different times. Lane 2-4 are recombinant plasmids after digestion for 50. 80, 110, 140 seconds, and lane 1 is DN 
Figure 3. DNA (middle row) and deduced amino acid (top row) sequences of cryIA(c) from Btk isolate of $\mathrm{B}$. thuringiensis and comparisons with that of cryIA (c) from B. thuringiensis subsp. kenyae HD588-2 (bottom). Underlines are sequences of primers used for gene cloning. Blue for silent mutation and red face for mutation causing changes of amino acids. 
ampicillin, and the colonies grown were examined for the presence of mutated plasmid. The results demonstrated that each of the clones examined carried recombinant plasmid mutated at several different levels (Figure is not presented).

Sequence of crylA gene fragment

The cryIA fragment of non-mutated gene and three uni-deleted mutants were used for sequencing. Electrophoregram of the nonmutated gene fragment shows that only around 500 by DNA sequence of the 5'-end and 500 by DNA sequence of the 3'-end could be read accurately. 
The rest DNA sequence of about $1-\mathrm{kb}$ in the middle of the gene should be completed by combining these sequences with those of three deletedmutants manually. By this way we finally got the full sequence. These results show that the construction of uni-deleted mutant series is a valuable way used for DNA sequencing. The use of this technique for sequencing of a gene is considered to have more advantages compared to the use of chromosome walking which takes more time. The latter approach requires at least four primers. In addition, it takes more time because the sequence of the $2^{\text {nd }}, 3^{\text {rd }}$, and 0 primers has to be designed based on the results of the $15,2 \mathrm{nd}$, and $3^{\text {d }}$ sequencings respectively.

Figure 3 shows the full nucleotide sequence of the cloned cryIA compared with that of cryIA gene from B. thuringiensis subsp. kenyae from which the forward and reverse primers were designed, and the deduced amino acids sequence. This sequence contains 2021 nucleotides encoding a protein of 673 amino acids that is greater than $99 \%$ identical to the protein encoded by cryIA(c) of $B$. thuringiensis subsp. kenyae. From the sequence, point mutations were detected on nucleotides number 444, 477, 1089, 1092, 1098, 1242, 1566, 18691906 and 1961. Seven of these mutations (nucleotides of 444, 477, 1089, 1092, 1242, 1566 and 1869) were identified as silent mutations, while the other three mutations changed the amino acids. The changes of amino acids were identified at the positions 366 (substitution of Leu for Phe), 636 (substitution of Leu for Val) and 654 (Tyr substituted Cys).

The high degree of sequence homology of the cloned cryIA to that of cryIA(c) from B. thuringiensis subsp. kenyae suggests that this 2-kb fragment belongs to cryIA(c) subclass and should encode protein that is toxic for Lepidopteran insect. Furthermore, bioassay of BT isolates from which the gene has been cloned showed a significant degree of toxicity to Lepidopteran insects of Setotosea asigna (Sudharto et al., 1998) and Conopomorpha cramerella (Widiastuti \& Santoso, 1996).

According to Hofte \& Whiteley (1989) the toxic domain is localized in the N-terminal half of the protoxin, and further analysis confirmed that the shortest toxic fragment domain was localized between codons 29 and 607 for CrylA(a), CrylA(b) and CrylA(c). Differences in three amino acids between this cryIA(c) gene fragment of Btk isolate compared to that of cryIA(c) from $B$. thuringiensis subsp., kenyae occur outside the 5 blocks of conserved region of $B$. thuringiensis toxin as identified by Hofte \& Whiteley (1989). Therefore this mutation or differences of the three amino acids are predicted not to affect the toxicity of the protein. However this prediction still wait for the biological assay for the toxicity and specificity of the protein.

\section{Conclusions}

CryIA(c) gene fragmen cloned from Btk isolate has been sequenced, by construction of a series of pGEM-cry mutants uni-directionally deleted at the 5' - end. The sequence contains 2021 nucleotides encod-ing a protein of 673 amino acids that is more than $99 \%$ identical to the protein encoded by crylA(c) of $\mathrm{B}$. thuringiensis subsp. kenyae. Ten point mutations were detected, seven of them (at the nucleotide 444, 477, 1089, 1092, 1242, 1566, and 1869) were identified as silent mutations, while the other three mutations (at the nucleotide 1098, 1906 and 1961) subtituted the amino acids. 


\section{References}

Aronson, A.I. (1993). The two faces of B. thuringiensis : Insecticide protein and post exponential survival. Mol. Microbiol., 7, 489-496.

Budiani , A., D. Santoso, A. Suwanto \& B.W. Lay (1996). Isolasi gen cryIA penyandi domain toksin pada S-endotoksin dari beberapa isolat Bacillus thuringiensis dengan teknik PCR. Menara Perkebunan, 64 (2), 93-104.

Budiani, A., D. Santoso, A. Suwanto \& B.W. Lay (1999). Cloning of cryIA fragment encoding toxin domain using pGEM-T vector. Jurnal Bioteknologi Pertanian, 4, 12-17.

Ceron, J., A. Ortiz, R. Quintero, L. Guereca \& A. Bravo (1995). Specific PCR primers directed to identify cryI and crylll genes within a $B$. thuringiensis strain collection. Appl. Environ. Microbiol., 61, 3826-3831.

Doyle, K. (1996). Promega Protocols and Application Guide. Third edition. Promega Corporation, Madison. p. 41-54.

Herrera, G., S.J. Snyman \& J.A. Thompson (1994). Construction of a bioinsecticidalstrain of Pseudomonas, luorescens active against the sugarcane borer, Eldana saccharina. Appl. Environ. Microbiol., 60, 682690.

Hofte, H. \& H. R. Whiteley (1989). Insecticidal crystal proteins of Bacillus thuringiensis. Microbiol. Rev., 53,242-255.

de Maagd, R. A., D. Bosch \& W. Steikema (1999). Bacillus thuringiensis toxin-mediated insect resistance in plants. Trends in plant science, 4,9-13.

Rogers, S.G. \& B. Weiss (1980). Exonuclease III of Escherichia coli K-12 an AP endonuclease. Methods Enzymol., 94, 441.

Sambrook, J., E.F. Fritsch \& T. Maniatis (1989). Molecular cloning, a laboratory manual, Book 2, 2"d. Ed. New York, Cold Spring Harbor Laboratory Press.

Samoso, D. (1998). Construction of a series of pGEM/CrylA mutant uni-directionally deleted at the 5' - end adjacent to the insert. Menara Perkebunan, 66(1), 29-35.

Santoso, D. (2000). Rekombinasi DNA untuk overekspresi gen cryIA dalam usaha perakitan tanaman kelapa sawit yang tahan terhadap ulat pemakan daun. Laporan RUT V 1997/1998-1999/ 2000. DRN, Jakarta. 58p.

Sanger, F., S. Nicklen \& A.R. Coulson (1977). DNA sequencing with chain terminating inhibitors. In Proc. Natl. Acad. Sci., 74, 5463-5467.

Schnable, P.S. (1991). Genetic engineering lab manual, Genetic 520L. Department of Genetics, Iowa State University, $47 \mathrm{p}$.

Shin, B.S., S.H. Park, S.K. Choi, B.T. Koo, S.T. Lee \& J.1. Kim (1995). Distribution of vryV type insecticidal protein genes in Bacillus thuringiensis subsp. Kurstaki and Bacillus thuringiensis subsp. Entonosidus. Applied Environ. Microbiol., 61, 2402-2467. 
Sudharto, Ps., Asmini B. \& D. Santoso (1998). Efikasi isolat beberapa galur Bacillus thuringiensis terhadap ulat api Setothosea asigna van Eecke. Warta PPKS, 6, 17-24

Tailor, R., J. Tippet, G. Gibb, S. Peles, D. Pike, L. Jordan \& S. Elly (1992). Identification and characterization of a novel $B$. thuringiensis endotoxin entomocidal to Coleopteran and Lepidopteran larvae. Mol. Microbiol., 6, 1211-1217.

Udayasurian, V., A. Nakamura, H. Mori, H. Masaki \& T. Uozumi (1994). Cloning of a new cryIA(a) gene from $B$. thuringiensis strain $F U-2-7$ and analysis of chimeric $C r y] A(a)$ proteins for toxicity. Biotech. Biochem., 58,830-835.

Von Tersch, M.A., H.L. Robbins, C. S. Jany \& T. B. Johnson (1991). Insecticidal toxins from $B$. thuringiensis subsp. kenyae: Gene cloning and characterization and comparison with $B$. thuringiensis subsp. kurstaki CryIA (c) toxins. Applied Environ. Microbiol., 57, 349-358.

Widiastuti, H. \& D. Santoso (1996). Toksisitas beberapa isolat Bacillus thuringiensis terhadap penggerek buah kakao dan karakteristik gen cry-nya. Menara Perkebunan, 64(3), 123132. 